No. 3 の泥率は著しく大となっている。

第 6 表の陽極試料 No. 2, No. 3 の全泥量を比較してみると, いずれも温度の上昇とともに泥量は減少しているが，その減少の 程度は $\mathrm{Zn}$ 含有率の高いNo, 3 試料において顥著である。これ は全泥量の5ち Cu 泥部分が同様な傾向を持ち，しかるNo.3 の 方が $\mathrm{Cu}$ 泥/全泥の割合が大であることによる。したがってこの ような傾向が $\mathrm{Zn}$ 含有率のより低い陽極材料の場合にる存在する とするならば， $\mathrm{Zn}$ 含有率の低い陽極材料ほど $\mathrm{Cu}$ 泥部分の温度 による減少の度合は少なくなり，また全泥のうち剔離によって生 成される泥の占める比率は增大することとなり, No. 1 に执いて 温度の上界により減少した泥が $50^{\circ} \mathrm{C}$ で再び增加している現象も このような理由により剩離泥が增加したためとす考えられる。

第 7 表を見るに，いずれの電流密度に沶いてる $\mathrm{Cu}$ 泥の量は $\mathrm{Zn}$ 含有率の大きいNo. 3 の方が大となってているが, 合金泥の量 は逆に小となっている。したがって全泥に対する合金泥の割合は No. 3 に拟いて著しく小となっている。No. 1 の泥量が No. 2, No. 3 の場合と異なり, 電流密度との間に判然とした傾向が見ら れない理由る剝離泥の占める割合が No. 2, No. 3 等にくらべて 大であるためと解される。

上記の諸結果からもわかるよ $5 k, \mathrm{Zn}$ 含有率の高い黄銅陽 梅 からの泥量は低い黄銅陽極からのあのに比較して大であるが，合 金泥の部分はむしろ $\mathrm{n}$ 含有率の高い放が僅かに少なくなって拉 り, 泥量の增加は $\mathrm{Cu}$ 泥部分の增加に由来するすのである。

\section{IV. 結語}

本研究においては，青銅を陽極として $\mathrm{H}_{2} \mathrm{SO}_{4}-\mathrm{CuSO}_{4}$ 電解液中 において電解する際に生成される金属泥を究明するための基碟研 究として, 青銅と類似の単相組織を持ち, 電気化学的にもほほ類 似の性質を有すると考えられる黄銅を選び，これを陽極として電 解する際生成される金属泥について，その生成に及ぼす諸因子の 影響を検討し次の結果をえた。

（1）泥量は一般には再現性が悪い。しかし使用前にあらかじ め材料を十分嘒鈍すれば再現性のよい值がえられる。

（2）黄銅陽極からの泥中には陽極材料組織の一部が混入して
いる。これは陽極の剩離によるるのと解される。したがってこの 部分の量を $\mathrm{Zn}$ 量から求めて「合金泥」とし，また泥中の全 $\mathrm{C}$ 量から合金泥に含まれる $\mathrm{Cu}$ を除いた残りの部分を「Cu泥」と して取报っだ。

（3）温度の上刑にともない，一般に $\mathrm{Cu}$ 泥は減少するが，合 金泥は逆にむしろ増加する傾向を示す。しかし合金泥の占める 的割合は比較的小さいので, 全泥量は $\mathrm{Cu}$ 泥と同様, 高温ほど少 なくなる傾向を持つ。

（4）泥量はるちろん電流密度が大になると增加するが，単位 通電量当りの值に換算した場合の泥量る電流密度の大きいほど大 である。この傾向は $\mathrm{Cu}$ 泥の同様な䝨向によるるのであって, 合 金泥は逆に高電流密度ほど减少する。

（5）電解液中の $\mathrm{CuSO}_{4}$ あるいは $\mathrm{ZnSO}_{4}$ の濃度の変化によ って泥量にはほとんど変化が認められないが， $\mathrm{H}_{2} \mathrm{SO}_{4}$ はその淡 度の增加にともない $\mathrm{Cu}$ 泥，合金泥をとるに增加させる值向が認 められる。

（6）陽極材料表面を機械的に研磨した場合には電解の初期に 打いて生成される泥量は $\mathrm{Cu}$ 泥，合金泥ともに著しく大となる。 また $\mathrm{H}_{2} \mathrm{O}_{2}$ により表面を酸化したるのも電解初期に打ける $\mathrm{Cu}$ 泥 の增加が認められるが，これをさらに $\mathrm{NH}_{3}$ のように $\mathrm{Cu}$ の酸化 物を錯塩をうくって溶解させる液で処理した場合には增加は全く 瑟められない。電解研磨して表面を平滑にした場合には逆に電解 初期の泥量はやや减少する。

（7）黄銅陽極から生成される泥量は純 $\mathrm{Cu}$ 陽極からのものに 比較して著しく多量であるが, 黄銅の中においてるとくに常温付 近では $\mathrm{Zn}$ 含有率の大きい方が泥量は大である。

（8）黄銅陽極から生成される金属泥の成因は, 合金泥に対し ては陽極材料の一部の剩離によると思われ，また $\mathrm{Cu}$ 泥に対して は一般には主とし過剩に生成された $\mathrm{Cu}^{+}$の化学的な分解による ものと思われる。

（本研究の一部は昭和 24 年 10 月, 昭和 25 年 11 月の電気 化学協会搼演会において発表)

\title{
鉛蓄電池陽極の電気化学的性 質
}

(昭 和 31 年 4 月 28 日 受 理)

長浦 茂男・加藤 栄三・山野 恒一郎*

\section{I. 序 言}

鉛蓄電池の性質は一般に陽極板の優劣により定まる。能率をよ くするためには陽極板の充放電に括ける物理的, 化学的性質を知 る必要がある。この目的に対して次の諸方法が考えられる。

1. 化学分析, $X$ 線扰よび電子線回折に上る化学組成の決定

2. 粒度計, 電子顕微鏡による粒子の形状㧍よび大きさの決定

3. 内部抵抗および静電容量測定に上る極板の表面状態決定

第 1 ，第 2 の方法については二，三の測定1)が行われ，著者ら2)

* 大阪市立大学理工学部：大陑市北区.

1）たとえば知久，“篦電池” p. 25 (1936) 岩波蓄店.

2）長浦，加藤，淵田，二アサ時報 No、27，17 (1955).
も充放電期間にお活る陽極脱落物質の組成, 粒度, 形状等を種 々 の物理化学的方法を用いて研究した。

しかしながら上記の研究は脱落したものについて行われ，必ず しも脱落機構を正確に捕捉すると思われない。ここで極板自体の 性質を知る方法が必要となる。そこで著者らは極板の性質に影督

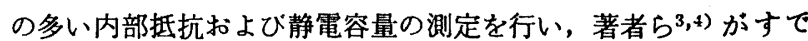
に金属極板について観測した分極抵抗および分極容量の考え方が かかる非金属極板にも適用しうるかをもあわせて検討した。

3) 長浦, 電化 19, 249 (1951).

4) S. Nagaura, K. Karaki, J. Inst. Polytech. Osaka City Univ. 5 C, 7 (1956). 


\section{II. 実 験 方 法}

使用した極板はできるだけ市肘ペースト式蓄電池と同一条件に するため，第 1 図の極板を自作し，陽極板製造と同じ方法で酸化 鉛より充填，乾燥，化成等の操作を施したすのを使用した。

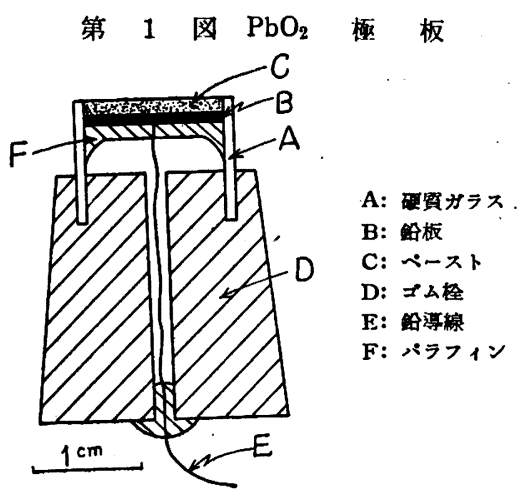

本研究においては著者らがすでに分極抵抗および分極容量測定 に用いた方法を払張した。すなわち垂直にした硬質ガラス管の下 端に陽極板を固定し, 直径 $1 \mathrm{~cm}$ の白金黒極板を上方から挿入し て, 一定距離における両極間の電気抵抗および静電容量を第 2 図 の回路で測定した。今, 測定槽に相応する等価回路を簡単のため 第 3 図のよ5に仮定すると，分極抵抗 $R \mathrm{~S}$ 扣よび分極容量 $C_{\mathrm{B}}$ は 次式で与えられる。

$$
\begin{aligned}
& R_{\mathrm{S}}=n R_{\mathrm{P}} \frac{1}{1+\omega^{2} C_{\mathrm{P}^{2}} R_{\mathrm{P}}^{2}} \approx n R_{\mathrm{P}} \\
& C_{\mathrm{S}}=\frac{C_{\mathrm{P}}}{n}\left(1+\frac{1}{\omega^{2} C_{\mathrm{P}}^{2} R_{\mathrm{P}}^{2}}\right) \approx \frac{1}{n \omega^{2} C_{\mathrm{P}} R_{\mathrm{P}}{ }^{2}} \\
& n=R_{\mathrm{B}} / R_{\mathrm{A}}
\end{aligned}
$$

第 2 闵 測定回路

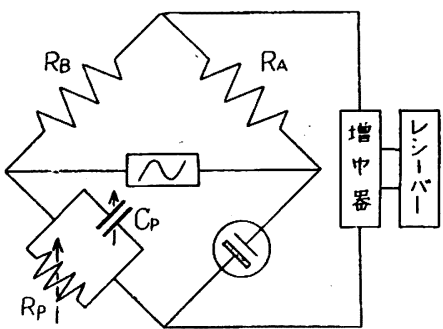

第 3 図等価问路

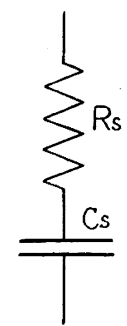

測定は充電直後の状態より定電流放電を行い，各段階の放電状 熊にしたものを，一定濃度の硫酸をみたした上記測定容器中で行 った。使用周波数は $1440 \mathrm{c} / \mathrm{s}$ であり，装置の構成上恒温槽を用 いることはできなかった。

\section{III. 実験結果および考察}

充電直後の極板に対して測定された内部抵抗および分極容量 は, 電導度夜の濃度に応じて第 4 図および第 5 図のごとく变化す る。距離を移動した時の内部抵抗の值は直線的になり，距離需へ の外挿值, すなわち分極抵抗は電導度液の濃度にかかわらず $1 \Omega$ に近い値をとる。また分極容量は一定值とならないで，距離を短 くするほど大きくなる傾向が認められる。充電状態では電極の実 際の表面積が著しく增大し，したがって央測される静電容量 $C_{\mathrm{P}}$ はあまりかわらずほとんど一定となり，RP のみが影響して $C_{\mathrm{s}}$ が距離ととすに变動するように思われる。な打分極容量は電導度
液の濃度増加とともに増大する傾向があり, この値は濃度分極に よるるの故従来の知見5)とよく一致する。

第 4 目充電直後の内部抵抗

ㅁ $5 \% \mathrm{H}_{2} \mathrm{SO}_{4} \triangle 10 \% \mathrm{H}_{2} \mathrm{SO}$

- $20 \%$ " $\bigcirc 30 \%$ "

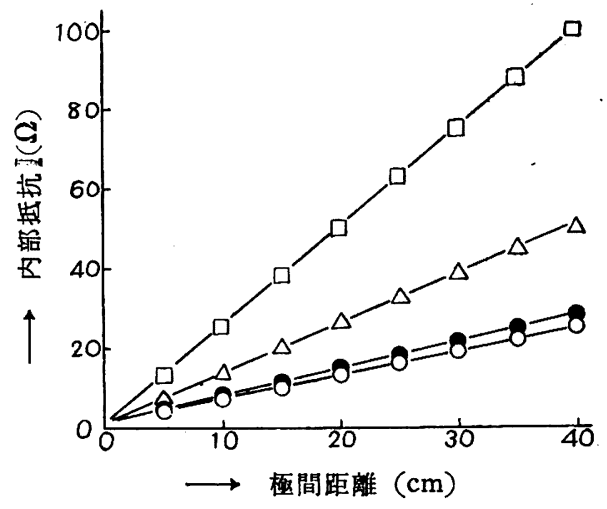

第 5 因充電直後の分極容量

$\square 5 \% \mathrm{H}_{2} \mathrm{SO}_{4}$, $\triangle 10 \% \mathrm{H}_{2} \mathrm{SO}_{4}$

- $20 \%$ " $030 \%$ "

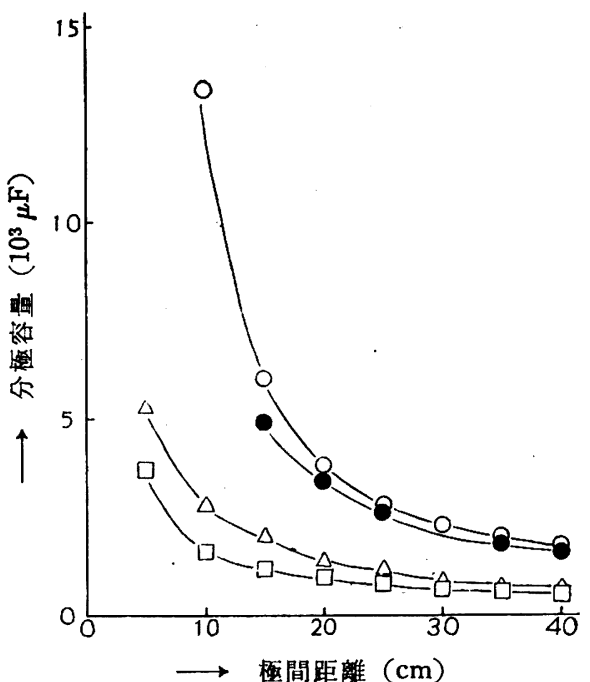

やや放電を行った極板すなわち端子電圧 $1.95 ， 1.85 ， 1.65 \mathrm{~V}$ のものに対しても全く同様の実験事実が認められる。

しかしながらさらに放電を続けた端子電圧 $1.50 \mathrm{~V}$ 以下の極板 については，分極抵抗は增大し，分極容量の距離による変動も少 なくなり，故電末状態ではその傾向は顕著である。その間の挙動 は第 6 図扣よび第 7 図で明白であろう。第 1 表に $30 \%$ 硫酸中に おける充電状態より放電状態に至る各極板に対する分極抵抗およ び分極容量の概略值を示した。ここでは分極容量の值は極間距離 $40 \mathrm{~cm}$ に打けるるのを示し, 比較のため鉛極板に対する測定值を も併記した。これによれば，多くの実験誤差は含まれているであ 万弓が, 充放電状態により分極抵抗の変化は約 500 倍, 分極容量 の変化は約 2000 倍という差異が観測される。

そのうえ極板面の外観上の変化として製造の際は凹面を呈して いるが化成，充電を行 5 と過酸化鉛よ5の赤カッ色の粗雑な平面 となり，放電後には凸状の美しい表面となるのが認められる。こ れは硫酸鉛生成に基く体積膨張を裏付ける事実である。著者ら

5) S. Nagaura, K. Sasaki, Bull. Chem. Soc. Japan 27 , 609 (1954).

6）長浦, 加藤, 紅浦, 未発表 
第 6 四充放電状熊 の内部抵抗 (電導度溶液は $30 \% \mathrm{H}_{2} \mathrm{SO}_{4}$ )

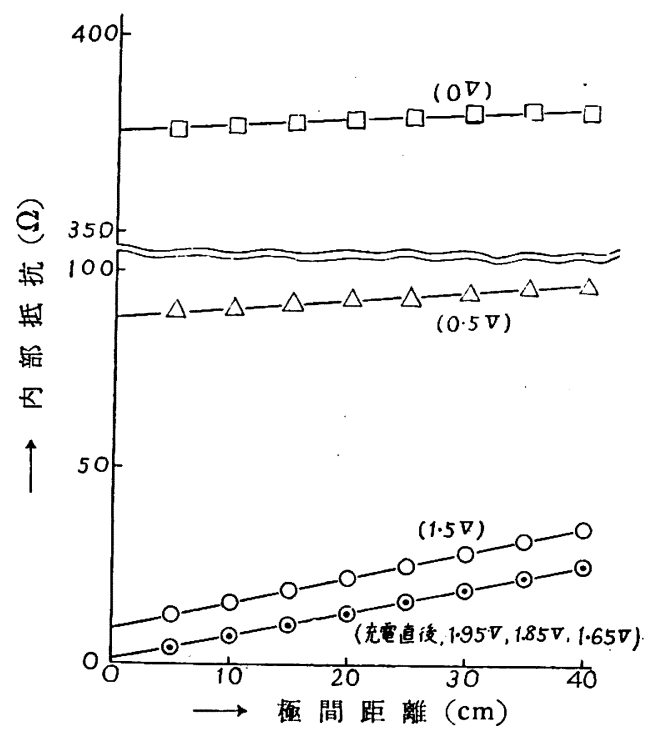

第 7 図充放電状熊の分極容琽 (電導度溶液は $30 \% \mathrm{H}_{2} \mathrm{SO}_{4}$ )

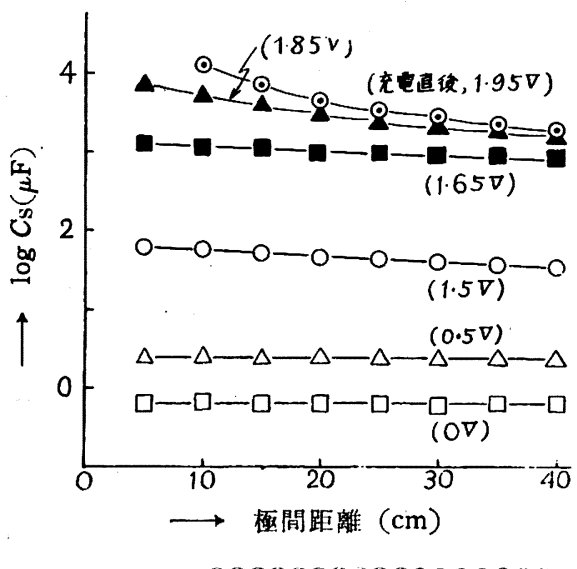

第 1 表 各充放電状態に括ける分極抵抗および分極容量*

\begin{tabular}{ccc}
$\begin{array}{c}\text { 極板の充 } \\
\text { 放電状態 }\end{array}$ & $\begin{array}{c}\text { 分極抵抗 } \\
(\Omega)\end{array}$ & $\begin{array}{c}\text { 分極容量 } \\
(\mu \mathrm{F})\end{array}$ \\
\hline 充電末 & $<1$ & 1,700 \\
$1.95 \mathrm{~V}^{* *}$ & $<1$ & 1,800 \\
1.85 & $<1$ & 1,500 \\
1.65 & $<1$ & 800 \\
1.50 & 9 & 30 \\
0.50 & 87 & 2.4 \\
0 & 375 & 0.62 \\
$\mathrm{~Pb}$ & $<1$ & 100
\end{tabular}

* $30 \%$ 硫酸における直径 $1.66 \mathrm{~cm}$ の円板に対する值を示す ** 端子電圧の值を示す

の陽極物質のX線および電子線回折の結果から，放電末状態にお いてもな打多量の過酸化鉛※ を残している点を考慮すれば，放電 により最初生成した硫酸鉛は極板の表面近傍のみに緻密な層をな し, 内部に多量の過酸化鉛を残存する。そうしてのち，その内部 のみで過酸化鉛はグリッドの鉛と自己放電を起して徐々に硫酸鉊 に変化するであろうと推察できる。放電中止による起電力の上昇 する事実, 放電末での使用や長時間放置が回復を困難にする点も この推論によって一応の説明がなしうる。

\section{IV. 緢 括}

（1）畒電池陽極板に，分極抵抗および分極容量なる概念を適 用した。その結果，充電状態から放電状態に進むにしたがい，分 極抵抗は著しく増大し，分極容量は著しく減少することが認めら れた。

（2）放電の際，最初表面のみに硫酸鉛の層が形成されること を推諭した。

※ 新しい極板についての実験によれば，硫酸鉛と過酸化銫の 組成比は同壁度と見なされている。

\section{浸清処理によってえられるアルミニウム酸化皮膜の耐食性}

（昭和 31 年 4 月 30 日受理）

\section{長 浦 茂男・村川敦 男*}

\section{緒}

アルミニウムの表面処理は陽極酸化以外に浸漬によっても酸化 皮膜をつくることができる。酸化性溶液は一般にクロム酸塩を主 成分とし M. B. V. 法1)を始め多数の特許がある。著者らは浸清法 によってえられる皮膜と陽極酸化皮膜との耐食性をミクロに比較 検討するために, リシ酸系の前処理剤 deoxidine*およびクロム 酸を主とした被覆処理㓮 alodine No. 1200*を用い高純度アルミ ニウム鋳塊を試料として実験を行った。不純物の種類を限定し，

* 大阪市立大学理工学部：大阪市北区.

1) G. Eckert, "The M.B.V. Surface Treatment for Aluminum and its Alloys," British Aluminum Company.

* American Chemical Paint Co.
またその所在を明らかにするためには高純度でかつ粒界がはっき りと現われている鋳塊が都合よく，主としてこの試料について浸 清被婹・陽極酸化を行い，それぞれを比較した。

\section{実験}

酎食試験には通常漫漬または噴雼法が用いられるが，著者らは それ以外に“アルミニウム酸化皮膜の表面状態の研究”2,3)の際に 用いた銅電着法を併用し，また腐食状況を顕微鏡下でできるだけ ミクロに観察した。表面状態を一定にするために試料はまず比重 1.5 のリン酸中で $0.5 \sim 1.0 \mathrm{~A} / \mathrm{cm}^{2}$ の電流密度で電解研磨した。 アルミニウムの純度は $99.84 \%$ で不純物として Si 0.08\%, Fe

2) 村川, 電化 23，355 (1955).

3）村川, 電化 24, 18 (1956). 